\title{
Application of a Broad Range Lytic Phage LPST94 for Biological Control of Salmonella in Foods
}

\author{
Md. Sharifull Islam ${ }^{1,2,3}$, Yang Zhou ${ }^{3,4}$, Lu Liang ${ }^{5}$, Ishatur Nime ${ }^{1}$, Ting Yan ${ }^{1}$, \\ Stephan P. Willias ${ }^{6}$, Md. Zakaria Mia ${ }^{7}$, Weicheng Bei ${ }^{2,3}$, Ian F. Connerton ${ }^{5}{ }^{(0)}$, \\ Vincent A. Fischetti ${ }^{8}$ and Jinquan $\mathrm{Li}^{1,3,8, *}$
}

1 Key Laboratory of Environment Correlative Dietology, College of Food Science and Technology, Huazhong Agricultural University, Wuhan 430070, China; smbgb101287@yahoo.com (M.S.I.); smbgb101287@gmail.com (I.N.); yantingau@163.com (T.Y.)

2 College of Veterinary Medicine, Huazhong Agricultural University, Wuhan 430070, China; beiwc@mail.hzau.edu.cn

3 State Key Laboratory of Agricultural Microbiology, Huazhong Agricultural University, Wuhan 430070, China; zhouyang@mail.hzau.edu.cn

4 College of Fisheries, Huazhong Agricultural University, Wuhan 430070, China

5 Division of Microbiology, Brewing \& Biotechnology, University of Nottingham, Sutton Bonington Campus, Loughborough, Leicestershire LE12 5RD, UK; sbzll3@nottingham.ac.uk (L.L.);

scziac@exmail.nottingham.ac.uk (I.F.C.)

6 Department of Infectious Diseases and Immunology, University of Florida, Gainesville, FL 32611-2015, USA; swillias@ehs.ufl.edu

7 Department of Microbiology, Jagannath University, Dhaka 1100, Bangladesh; mmzakaria@yahoo.com

8 Laboratory of Bacterial Pathogenesis and Immunology, The Rockefeller University, New York, NY 10065-6399, USA; vaf@mail.rockefeller.edu

* Correspondence: lijinquan2007@gmail.com

Received: 10 January 2020; Accepted: 11 February 2020; Published: 13 February 2020

Abstract: Salmonella, one of the most common food-borne pathogens, is a significant public health and economic burden worldwide. Lytic phages are viable alternatives to conventional technologies for pathogen biocontrol in food products. In this study, 40 Salmonella phages were isolated from environmentally sourced water samples. We characterized the lytic range against Salmonella and among all isolates, phage LPST94 showed the broadest lytic spectrum and the highest lytic activity. Electron microscopy and genome sequencing indicated that LPST94 belongs to the Ackermannviridae family. Further studies showed this phage is robust, tolerating a wide range of $\mathrm{pH}(4-12)$ and temperature $\left(30-60^{\circ} \mathrm{C}\right)$ over $60 \mathrm{~min}$. The efficacy of phage LPST94 as a biological control agent was evaluated in various food products (milk, apple juice, chicken breast, and lettuce) inoculated with non-typhoidal Salmonella species at different temperatures. Interestingly, the anti-Salmonella efficacy of phage LPST94 was greater at $4{ }^{\circ} \mathrm{C}$ than $25^{\circ} \mathrm{C}$, although the efficacy varied between different food models. Adding phage LPST94 to Salmonella inoculated milk decreased the Salmonella count by $3 \log _{10}$ $\mathrm{CFU} / \mathrm{mL}$ at $4{ }^{\circ} \mathrm{C}$ and 0.84 to $2.56 \log _{10} \mathrm{CFU} / \mathrm{mL}$ at $25^{\circ} \mathrm{C}$ using an MOI of 1000 and 10000 , respectively. In apple juice, chicken breast, and lettuce, the Salmonella count was decreased by $3 \log _{10} \mathrm{CFU} / \mathrm{mL}$ at both $4{ }^{\circ} \mathrm{C}$ and $25^{\circ} \mathrm{C}$ after applying phage LPST94 at an MOI of 1000 and 10,000, within a timescale of $48 \mathrm{~h}$. The findings demonstrated that phage LPST94 is a promising candidate for biological control agents against pathogenic Salmonella and has the potential to be applied across different food matrices.

Keywords: phage; LPST94; Salmonella; characterization; biological control 


\section{Introduction}

The diarrheal disease salmonellosis caused by non-typhoidal Salmonella spp. is one of the most frequent foodborne illnesses worldwide [1]. The major symptoms of Salmonella infection are abdominal pain, vomiting, inflammatory diarrhea, fever, and headache [2,3]. In the United States alone, Salmonella is annually responsible for $11 \%$ of illnesses, $35 \%$ of total hospitalizations, and $28 \%$ of deaths associated with food-borne diseases [4]. An outbreak was recently reported in Iowa, USA, where over 250 people were ill from consuming Salmonella contaminated chicken salad. Among them, one person died and more than 90 others were hospitalized [5]. In China, non-typhoidal Salmonella spp. are of concern with an estimated 414.8 cases occurring annually in Guangdong Province [6]. Salmonella commonly contaminates an extensive range of food products, including meat, eggs, milk, vegetables, and fruit juices. Salmonella contamination in food preparations typically arise from the natural association of the bacteria with products of animal origin and cross-contamination during processing services $[7,8]$.

Conventional control measures such as heat treatment or chemical preservatives can control pathogens, including various Salmonella serovars, in food products [9-11]. However, these measures run the risk of negatively affecting the taste of food products and reducing also nutritional availability $[12,13]$. Many chemical preservatives have been reported to have the potential for adverse side effects, including allergic contact dermatitis, convulsion, hives, asthma, diarrhea, intestinal hemorrhage etc. [14,15]. Thermal processing can negatively influence the quality of food products by destroying vitamins thus reducing their nutritional value [13]. Moreover, advanced glycation end-products (AGEs) that are produced by heat treatment have been considered as health-threatening complications [16]. Current methods to treat acute Salmonella gastroenteritis are dependent upon supportive care and antibiotic regimens. The overzealous application of antibiotics, especially in the farm setting, has led to the selection of antimicrobial-resistant strains $[17,18]$, which have contaminated food and water systems, and pose a worldwide threat. Under these circumstances, the measures employed to control Salmonella must not lead antimicrobial resistance, which has garnered interest in biological controls.

Although using phages for therapeutic purposes or as biocontrol agents is not entirely a new idea, in recent years, urged by the increasing development of drug-resistant bacteria, interest in phage therapy has been rekindled $[19,20]$. Phage as therapy offers many attractive advantages including pathogen-targeting, host-specificity, rapid killing, and self-replicating potential [21,22]. Phages are obligate viral parasites of bacteria which, through interactions with unique bacterial surface receptors, infect specific prokaryotes bearing the distinct molecular signatures. As such, phages exhibit extreme host-specificity which enables the selective targeting of certain bacterial genera or species. Considering phages only infect bacteria, they elicit little harm to eukaryotic cells, thereby affording a high degree of safety $[23,24]$.

Phages have been used for inactivation and control of food-borne pathogens, such as Salmonella in diverse food matrices [25-30]. Also, commercially available phage products such as SalmoFresh, Armament, Salmonelex have been used for inactivation and control Salmonella in food products [30,31]. Since bacteria and phage have co-evolved for billions of years, bacteria have developed multiple defense systems against phage [32,33]. It requires us to continuously provide new promising phages with relatively broad lytic range and high lytic activity for practical application. In the present study, 40 environmentally acquired phages were isolated and screened to determine their bacterial lytic range and lytic activity. The newly isolated phage LPST94 showed the greatest potential in respect of control zoonotic Salmonella in diverse food matrices.

\section{Materials and Methods}

\subsection{Bacterial Strains and Culture Conditions}

Salmonella enterica (UK-1, ATCC 13311) was used as the host strain for phages isolation. A total of 65 different bacterial strains, consisting of 40 Salmonella strains encompassing 11 distinct serovars as well as a cohort of 25 non-Salmonella strains, were used to determine the phage lytic range (Table S1). 
All bacterial strains were cultured by the streak plate method on tryptic soy agar (TSA; Difco ${ }^{\mathrm{TM}}, \mathrm{BD}$, USA) followed by overnight incubation at $37^{\circ} \mathrm{C}$.

\subsection{Enrichment, Isolation, Purification, and Preparation of Phages}

A total of 40 putative different phages were isolated from the environmentally sourced water samples collected in Wuhan, China in accordance with previously described methods [34,35]. Enrichment for phage isolation was modified from previously published methods [36]. In brief, $10 \mathrm{~mL}$ of exponential growth phase Salmonella cultures were mixed with $40 \mathrm{~mL}$ 2-YT broth medium (1.6 $\mathrm{g}$ of peptone, $1.0 \mathrm{~g}$ of yeast extract, and $0.5 \mathrm{~g} \mathrm{NaCl}$, in $100 \mathrm{~mL}$ of distilled water; $\mathrm{pH} 7.4$ ) and $10 \mathrm{~mL}$ of filtered water sample at a ratio of 1:4:1 (v/v/v) to amplify the collected phages. Amplified phages were isolated by centrifugation at $8000 \times g$ for $15 \mathrm{~min}$ and filtration using $0.22 \mu \mathrm{m}$ pore size disposable sterile syringe filters (Millipore, Ireland). The double layer agar method was used to determine the titer of the phage stock. Dilutions of the phage stock (100 $\mu \mathrm{L}$ each) were made in sterile SM buffer $\left(10 \mathrm{mM} \mathrm{NaCl}, 10 \mathrm{mM} \mathrm{MgSO}_{4}, 50 \mathrm{mM}\right.$ Tris:HCl, pH 7.5), mixed with a suspension of exponential phase Salmonella (about $10^{9} \mathrm{CFU} / \mathrm{mL}, 100 \mu \mathrm{L}$ ) and added to $4 \mathrm{~mL}$ of molten $\left(45^{\circ} \mathrm{C} \leq\right.$ temperature $\leq$ $50{ }^{\circ} \mathrm{C}$ ) tryptone soya broth (TSB) with agar $(0.7 \%)$. The mixtures were then poured onto the surface of tryptic soy agar (TSA) plates and were allowed to set at room temperature for $5 \mathrm{~min}$. Thereafter, the plates were incubated at $37^{\circ} \mathrm{C}$ for $24 \mathrm{~h}$, and resulting plaques were quantified. To purify the phages, individual plaques were picked using a pipette or a wire loop, and then suspended in TSB with exponential phase Salmonella at $37^{\circ} \mathrm{C}$ for $24 \mathrm{~h}$. The suspension was centrifuged $(8000 \times g$ for $15 \mathrm{~min}$ ) and filtered again using $0.22 \mu \mathrm{m}$ filters used as a single phage culture. The purification process was repeated at least four times, and then confirmed pure individual phage stock. High titer stocks of phage were prepared by mixing $100 \mu \mathrm{L}$ of the phage stock (about $9 \log _{10} \mathrm{PFU} / \mathrm{mL}$ ) with $100 \mu \mathrm{L}$ culture of Salmonella in $50 \mathrm{~mL}$ of TSB broth incubated for $12 \mathrm{~h}$ at $37^{\circ} \mathrm{C}$. The culture was centrifuged at $10,000 \times \mathrm{g}$ for $10 \mathrm{~min}$ and the supernatant was filtered through a disposable sterile syringe filter (0.22 $\mu \mathrm{m}$ pore Millipore, Ireland). The purified phages were stored at $4{ }^{\circ} \mathrm{C}$.

\subsection{Screening of Phages Based on Spot Test and Lytic Capacity}

\subsubsection{Lytic Spectrum Determination by Spot Test}

The ability of phages to lyse different serovars of bacteria was determined by spot test. In brief, $5 \mu \mathrm{L}$ of phage lysates were spotted onto lawns formed by the aforementioned 65 bacterial strains on TSA plates. The plates were incubated at $37^{\circ} \mathrm{C}$ for $24 \mathrm{~h}$. After incubation, any bacterial lawn with formation of clear plaques were considered as phage sensitive.

\subsubsection{Lytic Activity of Phage LPST94}

Lytic activity experiments were performed according to previously described method $[35,37]$. In brief, $100 \mu \mathrm{L}$ fresh overnight cultures of Salmonella $\left(7 \log _{10} \mathrm{CFU} / \mathrm{mL}\right)$ were added to $100 \mu \mathrm{L}$ of phage suspensions (MOIs 100, 10, 1, and 0.1) in a 96 well plate. The control group consisted of plain TSB medium in place of phage LPST94. Optical density $\left(\mathrm{OD}_{600}\right)$ was measured with a microplate reader (Infinite M200 Pro, Tecan, 140 Switzerland) at $37^{\circ} \mathrm{C}$, with a reading recorded every $1 \mathrm{~h}$ for a total duration of $24 \mathrm{~h}$. Response curves of lytic activity were generated using PRISM software.

\subsection{Efficiency of Plating}

Efficiency of plating (EOP) was determined as described previously [35,38]. Test bacterial strains were grown overnight at $37^{\circ} \mathrm{C}$ and $100 \mu \mathrm{L}$ of each of the test bacterial cultures was used in double layer assays together with $100 \mu \mathrm{L}$ of $10^{6}-10^{9}$-fold diluted phage lysate. The plates were incubated overnight at $37^{\circ} \mathrm{C}$. After incubation, the number of plaques were counted and the relative EOP was subsequently calculated (average PFU on test bacteria/average PFU on host bacteria). The average EOP values were classified as follows: +++ , EOP 0.5 to $1.0 ;++$, EOP 0.2 to $<0.5 ;+, 0.001$ to $<0.2 ;-,(<0.001)$. 


\subsection{Morphological Observation of Phage LPST94}

Prior to transmission electron microscopy, high titer phage LPST94 was obtained by pelleting phage with ultracentrifugation at $40,000 \times g$ for $1 \mathrm{~h}$, followed by re-suspending pellet in small volumes. Phage LPST94 was diluted into phosphate-buffered saline (PBS) and was negatively stained with $0.5 \%$ phosphotungstic acid (PTA) [34,39]. Thereafter, the phage was fixed on a copper grid and the images of the phages were captured using a Philips CM12 transmission electron microscope (Hitachi H-7000FA, Tokyo, Japan), at Wuhan Institute of Virology (China Academy of Sciences, Wuhan, China) and analyzed via Digital Micrograph Demo 3.9.1 software.

\subsection{Genomic Analysis of Phage LPST94}

Genomic DNA of the phage LPST94 was extracted and purified as described previously [40]. The genome was sequenced on the HiSeq platform (Illumina, San Diego, CA, USA) by means of a paired-end library with a $150 \mathrm{bp}$ read length. The sequences were assembled by using Newbler (v3.0) resulting in a unique contig. Putative coding DNA sequences (CDSs) were identified by Glimmer 3.0 [41]. Functional annotations of CDSs were identified by searching against the nr protein database using BLASTP [42]. The database ARG-ANNOT (http://backup.mediterranee-infection.com/article. php?laref $=282 \&$ titre $=$ arg-annot $)$ was used to detect the antimicrobial-resistant genes (ARGs) in phage. The database VFDB (http://www.mgc.ac.cn/VFs/main.htm) was used to detect the virulent factor in phage. The genome map constructed by using BRIG.jar software. The complete genome sequence of phage LPST94 has been deposited in GenBank under the accession number MH523359.

\subsection{One-Step Growth Curve}

One-step growth curve experiments were carried out to determine the phage LPST94 latent period and burst size essentially as described previously [43,44]. Briefly, S. Typhimurium UK-1 was grown to mid-log phase and $1 \mathrm{~mL}$ of bacterial culture (about $7.3 \log _{10} \mathrm{CFU} / \mathrm{mL}$ ) was combined to $1 \mathrm{~mL}$ of phage lysate (about $4.3 \log _{10} \mathrm{PFU} / \mathrm{mL}$ ) to achieve a multiplicity of infection (MOI) of 0.001 . The mixture was incubated for $20 \mathrm{~min}$ at $37^{\circ} \mathrm{C}$ and was subsequently centrifuged at $7000 \times g$ for $2 \mathrm{~min}$. The supernatant was discarded, and the pellet was washed twice with TSB broth. The pellet was then suspended in $10 \mathrm{~mL}$ of TSB broth and incubated at $37^{\circ} \mathrm{C}$, and $200 \mu \mathrm{L}$ samples collected at $10 \mathrm{~min}$ intervals over $3 \mathrm{~h}$ from which phage titers were determined by the double layer agar plate method [45] to establish a one-step curve. The latent period was defined as the time interval between absorption and the beginning of the first burst. The burst size was calculated as the ratio of the final number of phage particles to the initial number of infected host cells at the beginning of the test [33,34].

\section{8. $\mathrm{pH}$ and Thermal Tolerance of the Phage LPST94}

To determine the effect of $\mathrm{pH}$ on the stability of phage LPST94, phage lysates $\left(8.49 \log _{10} \mathrm{PFU} / \mathrm{mL}\right)$ were added to tubes containing sterile buffered peptone water (BPW) with $\mathrm{pH}$ values ranging from 2 to 13 adjusted with $\mathrm{NaOH}$ or $\mathrm{HCl}$. The tubes were allowed to incubate at $37^{\circ} \mathrm{C}$ for $60 \mathrm{~min}$. Thereafter, the phage solutions were serially diluted and the recovered phage titers were determined using $S$. Typhimurium UK-1 as a host by means of the double-layer agar method [46]. For the evaluation of thermal stability, the phage LPST94 lysates $\left(8.49 \log _{10} \mathrm{PFU} / \mathrm{mL}\right)$ were incubated at $30{ }^{\circ} \mathrm{C}, 40{ }^{\circ} \mathrm{C}$, $50{ }^{\circ} \mathrm{C}, 60^{\circ} \mathrm{C}, 70^{\circ} \mathrm{C}$, and $80^{\circ} \mathrm{C}$ for $1 \mathrm{~h} \mathrm{[37].} \mathrm{After} 30$ or $60 \mathrm{~min}$ of incubation, aliquots were extracted to determine phage titers through the application of the double-layer agar method.

\subsection{Phage Stability in Diverse Food Samples}

Phage stability experiments were conducted according to a previously described method [47] with little modification. Briefly, the phage was added in the milk, apple juice, chicken breast, and lettuce to reach a final titer of $7 \log _{10} \mathrm{PFU} / \mathrm{mL}$. All inoculated samples (milk, apple juice, chicken breast, and lettuce) were incubated at $25^{\circ} \mathrm{C}$ for $0,1,3,6,12,24$, and $48 \mathrm{~h}$. At each time-point, food samples 
(milk or apple juice or pre-cut chicken breast or lettuce) were taken to measure phage titer by using double-layer agar method.

\subsection{Ability of Lysogenic Formation of the Phage}

To confirm that phage LPST94 was unable to form lysogen, lysogenic induction was performed with phage-resistant bacterial colonies [48]. A single colony of purified bacteria was inoculated into tube with $5 \mathrm{~mL}$ TSB medium and stress-induced with mitomycin C (Sigma Chemical, St. Louis, MO, USA) to a final concentration of $1 \mu \mathrm{g} / \mathrm{mL}$. The samples were incubated overnight at $37^{\circ} \mathrm{C}$. After incubation, the bacteria were pelleted by centrifugation at $10,000 \times g$ for $10 \mathrm{~min}$ and the supernatant was examined for the presence of phages. The presence of a clear zone after stress-inducing indicates that bacteria contain prophage in their genome.

\subsection{Biological Control of Salmonella in Foods Using Phage LPST94}

\subsubsection{Testing in Milk and Apple Juice}

Pasteurized milk and apple juice were purchased from a local supermarket. Salmonella biocontrol experiments using phage LPST94 were conducted at $4{ }^{\circ} \mathrm{C}$ (refrigeration temperature) and $25{ }^{\circ} \mathrm{C}$ (room temperature) described previously [49]. Experimental groups were temperature acclimated for $20 \mathrm{~min}$ before $9 \mathrm{~mL}$ of milk or apple juice was spiked with $S$. Typhimurium ATCC 14028 or by a mixture of $S$. Typhimurium ATCC 14028 and S. Enteritidis ATCC 13076 to a final count of $3.5 \log _{10} \mathrm{CFU} / \mathrm{mL}$. Phage LPST94 was then added to an MOI of 1000 or 10,000. Aliquots were removed after 0, 1, 3, 6, 12, 24 and $48 \mathrm{~h}$ incubation. For Salmonella enumeration, $100 \mu \mathrm{L}$ of 10 -fold serial diluted samples were plated, giving the detection limit of $1 \mathrm{CFU} / 100 \mu \mathrm{L}$, and the plates were incubated for $48 \mathrm{~h}$ at $37^{\circ} \mathrm{C}$.

\subsubsection{Testing in Chicken Breast and Lettuce}

Chicken breast and lettuce were obtained from a local supermarket then sliced aseptically in the laboratory. The chicken breast was cut into pieces $(1 \mathrm{~cm} \times 1 \mathrm{~cm}$ square and $0.5 \mathrm{~cm}$ thick) using a sterile scalpel blade on the sterile station board. Similarly, the inner leaves of the lettuce were cut into pieces $\left(1 \mathrm{~cm} \times 1 \mathrm{~cm}\right.$ square) using a sterile sharp knife. The $1 \mathrm{~cm}^{2}$ food sections were placed in the center of the sterile petri-dishes and inoculated $S$. Typhimurium ATCC 14028 or a mixture of S. Typhimurium ATCC 14028 and S. Enteritidis ATCC 13076 to a final viable count of $3 \log _{10}$ CFU/cm². Phage LPST94 was then transferred on the sample surface with an MOI of 1000 or 10,000. These petri-dishes were incubated at $4{ }^{\circ} \mathrm{C}$ or $25^{\circ} \mathrm{C}$ for $48 \mathrm{~h}$ with lid on. After incubation, the sample was transferred to $2 \mathrm{~mL}$ Eppendorf tube and $1 \mathrm{~mL}$ PBS buffer was added to the sample in a sterile environment. The chicken breast and lettuce samples were homogenized with sterile bars and vortexed. The proportions of recoverable bacteria among the control group and the experimental group were determined by direct spread plate methods [47].

\subsection{Statistical Analysis}

Bacteria and phage counts were determined by duplicate plating, and all experiments were completed using a minimum of three biological replicates. Results are presented as mean value and variance were determined by the standard deviation from the mean. Statistical analyses were performed with PRISM software. Multivariate comparisons were performed using nonparametric one-way analysis of variance (ANOVA) with Bonferroni's multiple-comparison posttest.

\section{Results}

\subsection{Isolation and Screening of Phage}

A total of 40 putative different phages were isolated from environmentally-sourced water samples with either Salmonella enterica serovar Typhimurium UK-1 or ATCC 13311 as host bacteria. Differences 
in plaque size and turbidity were observed between each isolate. A collection of Salmonella strains was applied to determine the host range of all phage isolates with the same titer. The results of spot test showed that, of these phages, $22.5 \%$ of the isolates (9 out of 40 ) formed clear plaques and were capable of lysing more than $50 \%$ of the Salmonella test strains (Table 1), whereas the rest were specific to the initial isolation host. Spot tests indicated that phage LPST94 had the broadest lytic range. Phage LPST94 lysed all 40 Salmonella strains tested in this study that represent 11 Salmonella serovars and include drug-resistant Salmonella. However, all the phage isolates were unable to lyse E. coli or any of the Gram-positive and Gram-negative bacteria tested (Table 1).

Table 1. Sensitivity of different Salmonella serovars and other bacterial strains against selected phages determined by spot testing.

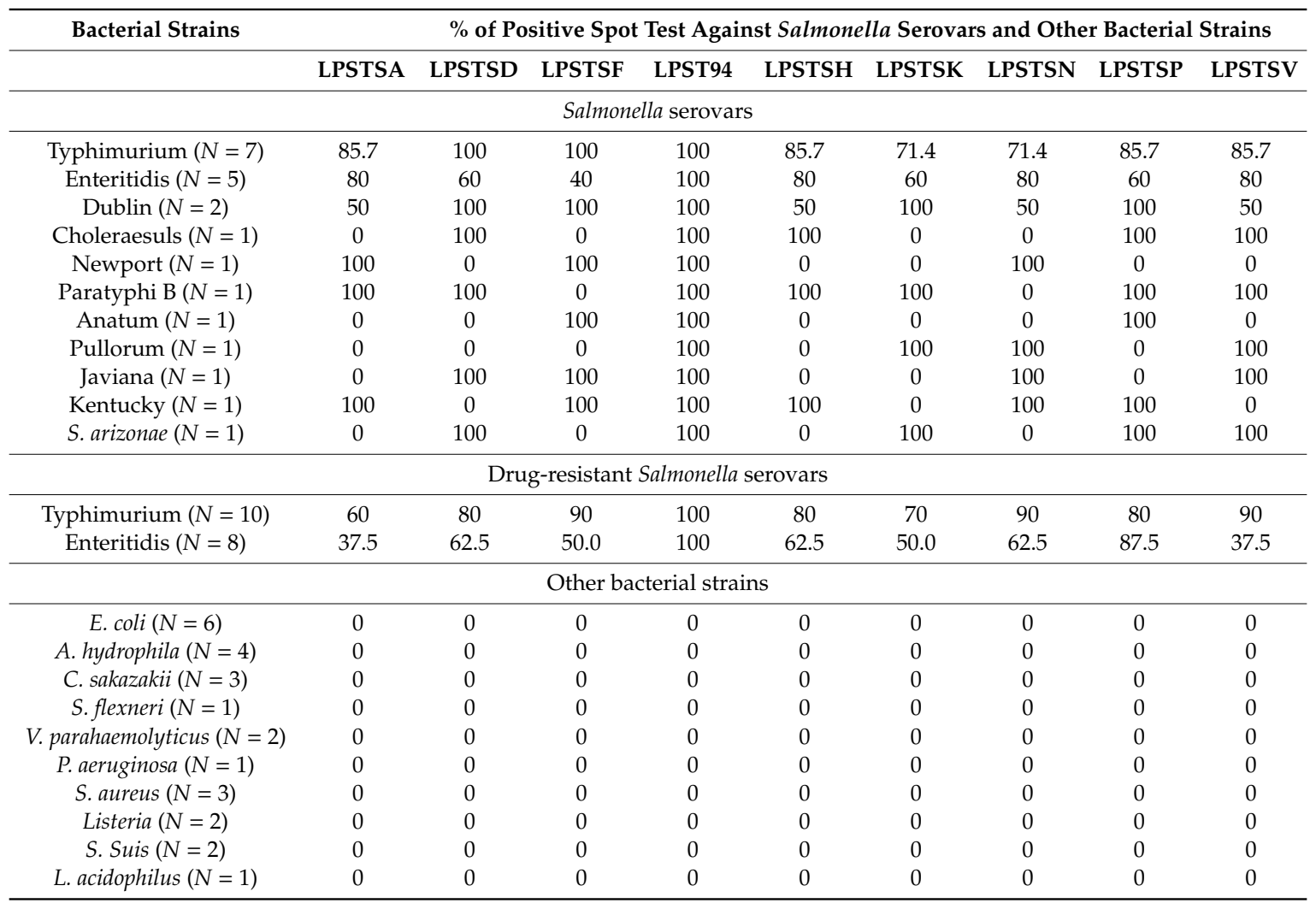

The lytic activity of these 9 wider lytic range phages were further evaluated using a challenge test against their initial isolation host Salmonella enterica serovar Typhimurium UK-1. As shown in Figure 1A, LPST94 successfully inhibited the growth of host bacteria over $12 \mathrm{~h}$ whereas the growth of host bacteria recommenced $4 \mathrm{~h}(p<0.05)$ after infection with all other phages (LPSTSA, LPSTSD, LPSTSF, LPSTSH, LPSTSK, LPSTSN, LPSTSP, and LPSTSV). To further establish the inhibitory activity of LPST94, we examined two $S$. Typhimurium (Figure 1B,C) and two $S$. Enteritidis (Figure 1D,E) strains for $24 \mathrm{~h}$ over a range of MOI $(0.1,1,10$ and 100$)$. The growth of both $S$. Typhimurium and $S$. Enteritidis were inhibited for 11-12 h $(p<0.05)$ after adding phage LPST94 at MOIs of $0.1,1,10$ and 100. Although the bacteria started growing after $12 \mathrm{~h}$, a significant differences were observed when applying different MOIs ( $p<0.05$; paired ANOVA). Generally, a greater sustained inhibitory effects were observed when phage was applied at higher MOIs. 

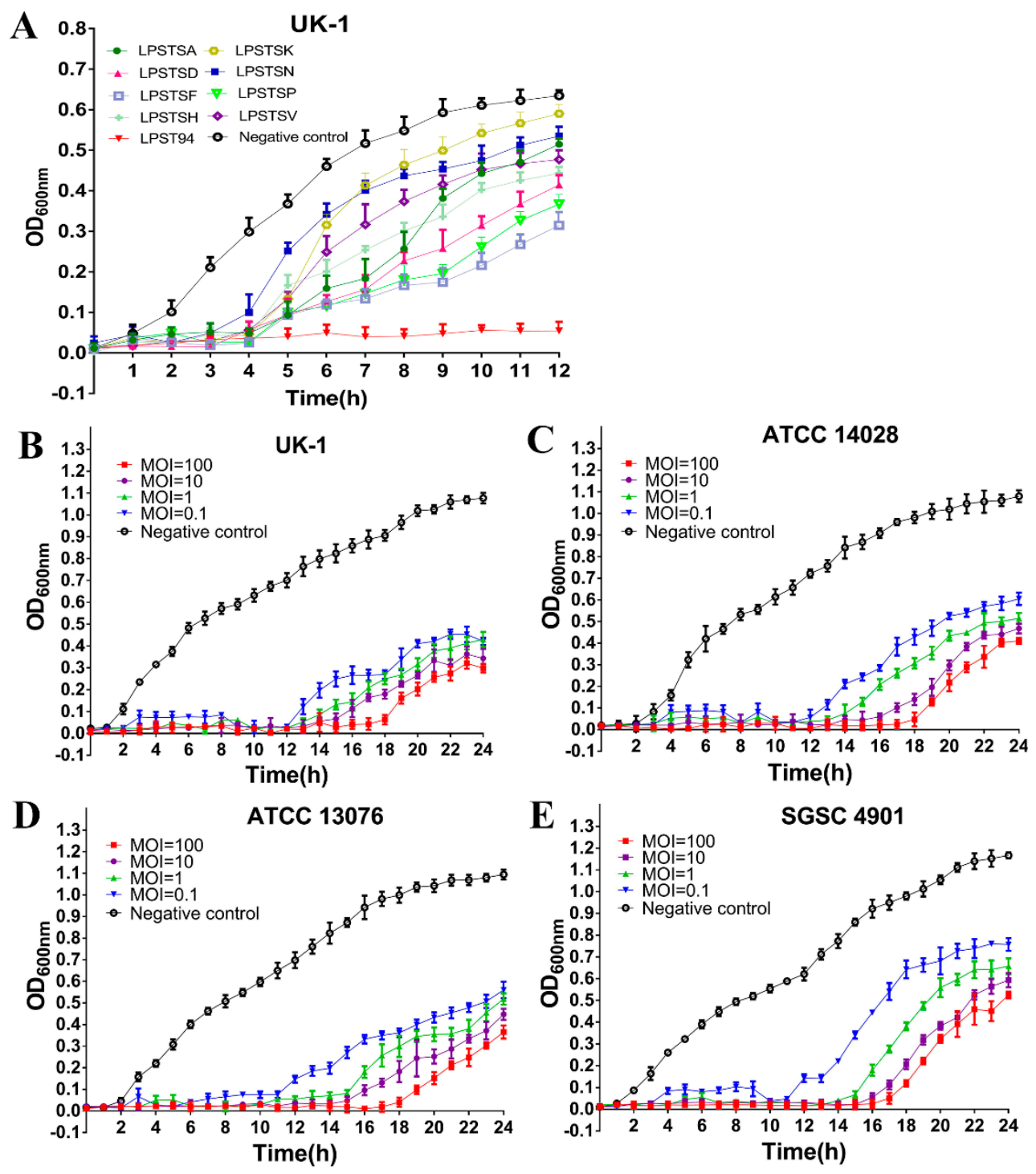

Figure 1. (A) Comparison of the lytic ability of selected phages using S. enterica serovar Typhimurium (UK-1) as a host at multiplicity of infection (MOI) of 1 in tryptone soy broth; Lytic ability of phage LPST94 to lyse $S$. Typhimurium and $S$. Enteritidis in tryptone soy broth medium at MOIs of 100, 10, 1, and 0.1 at $37^{\circ} \mathrm{C}$ in vitro. (B) S. Typhimurium UK-1, (C) S. Typhimurium ATCC 14028, (D) S. Enteritidis ATCC 13076, and (E) S. Enteritidis SGSC 4901. Values represent means with the standard deviation of three replicates of each time point.

\subsection{Relative Replication Efficiency of Phage LPST94}

As noted by Mirzaei et al. single dilution spot tests may show false positive results by lysis from without, bacteriocins in the phage lysate, or the existence of prophages [50]. Here, an EOP test was carried out to confirm the host range of phage LPST94 (Table 2). This phage had a high efficiency ( 0.5 to 1.0$)$ to infect the majority of $S$. Typhimurium strains compared with its isolation host $S$. Typhimurium UK-1, but the EOP values were moderate $(0.2$ to $<0.5)$ for some $S$. Enteritidis and drug-resistant Salmonella strains. The EOP of LPST94 phage was also analyzed on 18 drug-resistance Salmonella strains from our collection (the drug-resistance profiles of the 18 isolates of Salmonella are presented in Table S4). Clear plaques were observed for all 18 strains with relative EOP values ranging from 0.001 to $<0.2$. These results suggest that the phage LPST94 is capable of lysis over a range of Salmonella that contaminate foods (Table 2). 
Table 2. Efficiency of plating (EOP) by phage LPST94 against different Salmonella serovars.

\begin{tabular}{|c|c|c|c|}
\hline Bacterial Strains & EOP of LPST94 & $\begin{array}{l}\text { Drug-Resistance } \\
\text { Salmonella }\end{array}$ & EOP of LPST94 \\
\hline $\begin{array}{l}\text { S. Enterica serovar } \\
\text { Typhimurium }\end{array}$ & & $\begin{array}{l}\text { S. Enterica serovar } \\
\text { Typhimurium }\end{array}$ & \\
\hline ATCC 14028 & +++ & LST10 & + \\
\hline ATCC 13311 & +++ & LST11 & ++ \\
\hline UK-1 & +++ & LST12 & ++ \\
\hline ST8 & +++ & LST13 & ++ \\
\hline SGSC 4903 & +++ & LST14 & + \\
\hline SL 1344 & +++ & LST15 & + \\
\hline LT2 & +++ & LST16 & + \\
\hline $\begin{array}{l}\text { S. enterica serovar } \\
\text { Enteritidis }\end{array}$ & & LST17 & ++ \\
\hline ATCC 13076 & ++ & LST18 & + \\
\hline SJTUF 10978 & + & LST19 & + \\
\hline SJTUF 10984 & + & $\begin{array}{l}\text { S. enterica serovar } \\
\text { Enteritidis }\end{array}$ & \\
\hline LK5-3820 & ++ & LSE6 & + \\
\hline SGSC 4901 & ++ & LSE7 & + \\
\hline S. enterica serovar Dublin & & LSE8 & ++ \\
\hline 3710 & + & LSE9 & ++ \\
\hline 3723 & + & LSE10 & + \\
\hline $\begin{array}{l}\text { S. enterica serovar } \\
\text { Choleraesuis }\end{array}$ & & LSE11 & + \\
\hline ATCC 10708 & + & LSE12 & + \\
\hline $\begin{array}{c}\text { S. enterica serovar } \\
\text { Newport }\end{array}$ & & LSE15 & + \\
\hline E20002725 & + & & \\
\hline $\begin{array}{c}\text { S. enterica serovar } \\
\text { Paratyphi B }\end{array}$ & & & \\
\hline $\begin{array}{l}\text { CMCC } 50094 \\
\text { S. enterica Serovar } \\
\text { Pullorum }\end{array}$ & ++ & & \\
\hline CVCC 519 & + & & \\
\hline S. enterica serov & Javiana & & \\
\hline $\begin{array}{l}\text { CVM } 35943 \\
\quad \text { S. enterica serov }\end{array}$ & Anatum $^{+}$ & & \\
\hline $\begin{array}{l}\text { ATCC } 9270 \\
\quad \text { S. enterica serova }\end{array}$ & Kentucky & & \\
\hline $\begin{array}{l}\text { CVM } 29188 \\
\text { S. enterica A }\end{array}$ & onae + & & \\
\hline CDC 346-86 & + & & \\
\hline
\end{tabular}

+++ , EOP 0.5 to $1.0 ;++$, EOP 0.2 to $<0.5 ;+, 0.001$ to $<0.2$.

\subsection{Phage Morphology and Genomic Analysis}

Transmission electron microscopic examination of phage LPST94 showed that it has an icosahedral head and a long, rigid and relatively thick contractile tail that terminates in a baseplate with spikes. Its head is $67.60 \pm 2.30 \mathrm{~nm}$ in diameter $(n=6)$ and its tail is $116.30 \pm 4.10 \mathrm{~nm}$ long $(n=6)$ (Figure 2A). The morphology suggests that LPST94 belongs to the Ackermannviridae or Myoviridae family, in the order of Caudovirales. The genome size of LPST94 was 156,548 bp with a GC content of $44.6 \%$. BlastN analysis shows the genome of phage LPST94 has a high degree of homology with phage PhiSH19 in the database (Genbank Acc. No. JN126049). Compared with PhiSH19 phage, LPST94 has additional ORFs encoding tail fiber and tail spike proteins. The multiple tail fiber and tail spike proteins might be the reason for the broad lytic range observed. The genome of phage LPST94 contained 197 predicted ORFs (Figure 2B and Table S2) responsible for structure, replication/recombination/repair, nucleotide 
metabolism, transcription, translation and additional phage functions. They also include structural genes for phage assembly including the major capsid protein, prohead core protein, prohead protease, head completion protein, and tail/neck structure proteins. The genome encodes all the components necessary to complete the phage structure. The replication/recombination/repair gene modules encode replication proteins (DNA helicases, DNA polymerases, rIIA and rIIB proteins, DNA primase etc.) and recombination/repair proteins (single-stranded DNA binding protein, RecA-like recombination protein, DNA repair/recombination protein, recombination protein subunit), suggesting that this phage has its own replication/recombination/repair system. The module for nucleotide metabolism encodes putative dUTP diphosphatase, thymidylate synthase, ribonucleotide diphosphate reductase beta subunits etc. Gene functions fortranscription/translation are encoded by a sigma transcription factor, Gp33 late promoter transcription factor and RegA translational repressor protein. The LPST94 genome encodes a number of additional proteins, such as serine/threonine phosphatase for amino acid biosynthesis, PhoH-like protein for phosphate starvation and glutaredoxin (Figure 2B and Table S2). ARG-ANNOT database, VFDB database and BLASTP searches indicate that the LPST94 genome does not encode recognizable virulence factors, toxins, drug-resistant or integrase encoding genes, suggesting that the phage is safe and has the potential to be developed as an alternative antimicrobial agent. BLAST analysis confirmed that LPST94 belongs to the Ackermannviridae family, in the order of Caudovirales (Table S3). The complete genome sequence of phage LPST94 was deposited in GenBank under the accession number MH523359.

A

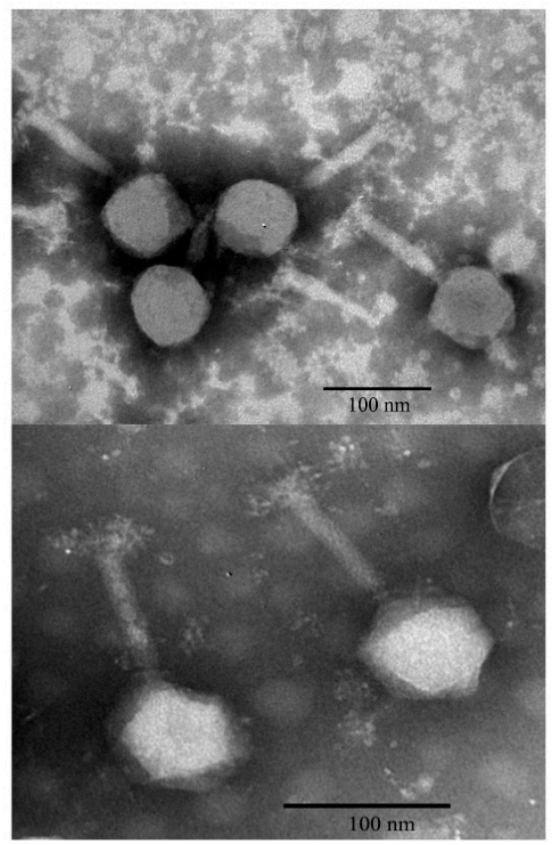

B

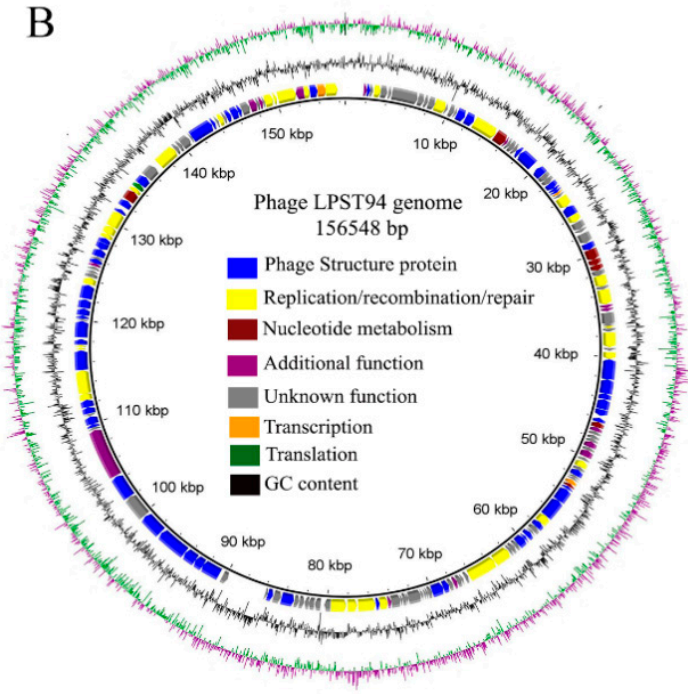

Figure 2. Morphological and genomic characteristics of phage LPST94. (A) TEM image of phage LPST94; Bar $100 \mathrm{~nm}$, and (B) Genome map of phage LPST94. Patterns were divided into four circles: the full length of the genome was indicated in the first circle; the open reading frame was indicated in the second circle, and the clockwise arrow and the counterclockwise arrow represented the forward reading frame and the reverse reading frame, respectively; GC content was indicated in the third circle; while on the fourth circle, GC skew of G-C/G+C was indicated as green and purple, and green meant the values of GC skew greater than 0 and purple meant the values less than 0 . The open reading frames marked with the color of each gene refers to the functional category: phage structure (blue), replication/recombination/repair (yellow), nucleotide metabolism (maroon), transcription (orange), translation (green) additional function (purple) and hypothetical proteins (grey). The genome map generated by the BRIG.jar software. 


\subsection{Characteristics of Phage LPST94}

The characteristics of phage LPST94 are shown in Figure 3. According to the one-step growth curve, the latent period was approximately $10 \mathrm{~min}$ and the average burst size was $145 \pm 10 \mathrm{PFU} / \mathrm{cell}$ (Figure $3 \mathrm{~A}$ ). This phage is very stable with a $\mathrm{pH}$ range from 4 to 12, however, phage titers were reduced when the $\mathrm{pH}$ was in the higher $(\mathrm{pH}>12)$ or lower $(\mathrm{pH}<4)$ ranges (Figure $3 \mathrm{~B})$. The phage had a high degree of thermal tolerance, with stability as high as $60^{\circ} \mathrm{C}$ but reduced at $70^{\circ} \mathrm{C}$ and $80^{\circ} \mathrm{C}$ (Figure $3 \mathrm{C}$ ). By incubating phage within food matrices including milk, chicken breast, and lettuce the phage showed either no difference or minimal titer reduction within the experimental timescale of $48 \mathrm{~h}$. However, the phage titer fell by approximately $2.5 \log \mathrm{PFU} / \mathrm{mL}$ after $48 \mathrm{~h}$ incubation in apple juice (Figure 3D). Lysogenic induction assay results showed that LPST94 phage-resistant Salmonella were unable to lysogens (Figure S1). In summary, phage LPST94 remained stable under all test conditions described above and may be a promising candidate to control Salmonella in foods.
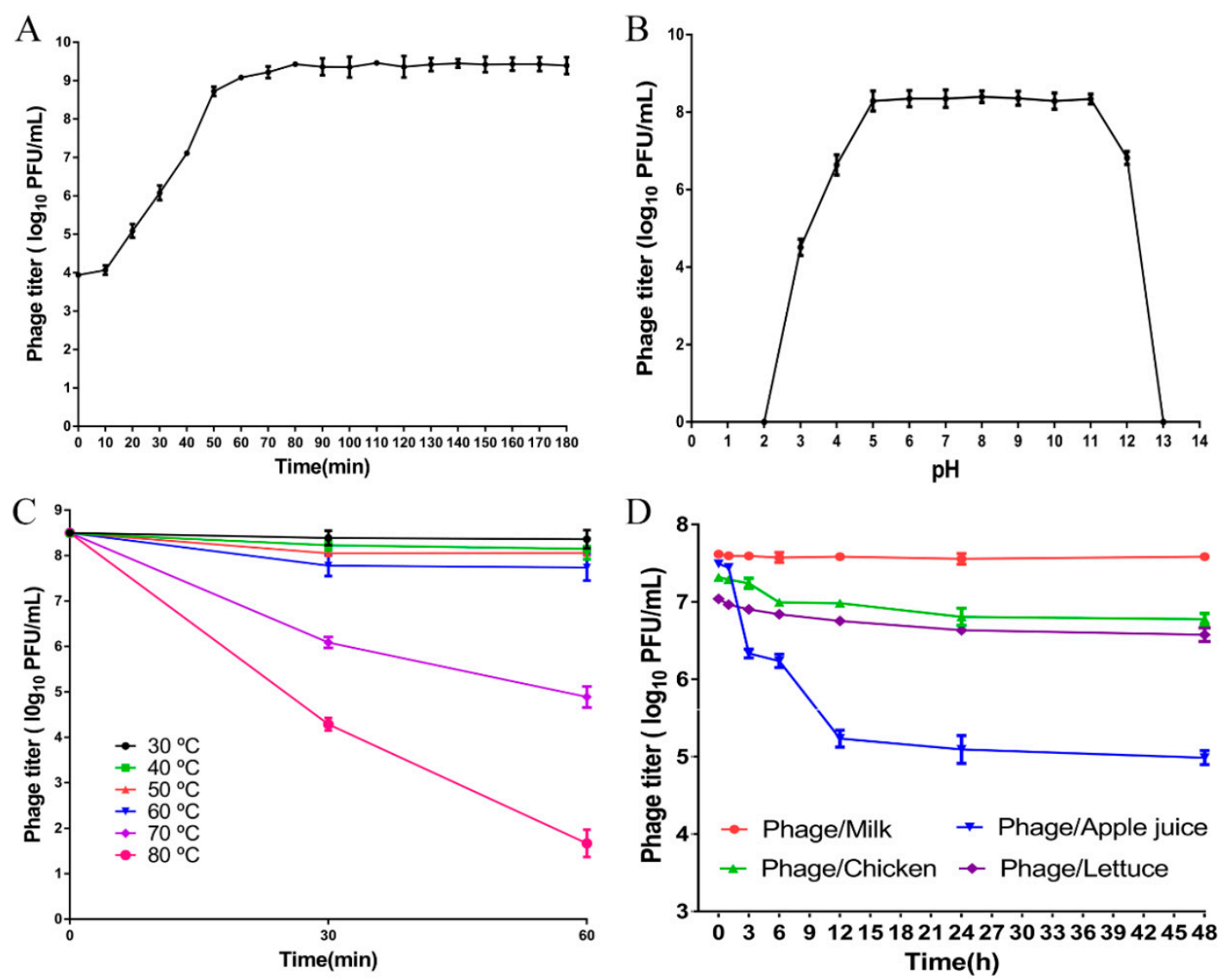

Figure 3. Characteristics of phage LPST94. (A) One-step growth curves of phage LPST94 with Salmonella enterica serovar Typhimurium UK-1 host infected at $37^{\circ} \mathrm{C},(\mathbf{B}) \mathrm{pH}$ tolerance of phage LPST94 ( $\mathrm{pH} 2$ to 13), (C) Temperature tolerance of phage LPST $94\left(30{ }^{\circ} \mathrm{C}\right.$ to $\left.80^{\circ} \mathrm{C}\right)$, and (D) Stability of phage LPST94 in four food samples (milk, apple juice, chicken breast, and lettuce) at $25^{\circ} \mathrm{C}$. Values represent mean with standard deviation of three determinations of each point.

\subsection{Application of Phage LPST94 in Controlling Food-Borne S. Typhimurium and S. Enteritidis}

Salmonella attributed outbreaks are often associated with animal products including poultry, raw meat, dairy production, but also include products such as salad dressing and fruit juice [51]. In this study, the efficiency of phage LPST94 was assayed in different food matrices against $S$. Typhimurium and $S$. Enteritidis. 


\subsubsection{Milk}

Milk was inoculated with S. Typhimurium (ATCC 14028) alone or a mixture of Salmonella (S. Typhimurium ATCC 14028 and S. Enteritidis ATCC 13076) to a final viable count of $3.5 \log _{10} \mathrm{CFU} / \mathrm{mL}$. After incubation with phage LPST94, the viable count of the $S$. Typhimurium in milk was reduced below the detection limit $(<1 \mathrm{CFU} / 100 \mu \mathrm{L})$ after $12 \mathrm{~h}$ and $24 \mathrm{~h}$ at $4{ }^{\circ} \mathrm{C}$ using an MOI of 10,000 and 1000 , respectively (Figure $4 \mathrm{~A}$ ). At $25^{\circ} \mathrm{C}$ after $48 \mathrm{~h}$ incubation, the viable count of Salmonella decreased from $3.5 \log _{10} \mathrm{CFU} / \mathrm{mL}$ down to 2.56 and $0.84 \log _{10} \mathrm{CFU} / \mathrm{mL}$ with phage added to an MOI of 10,000 and 1000, respectively (Figure 4B). Similar results were observed when using phage LPST94 to infect the mixture of Salmonella (S. Typhimurium ATCC 14028 and S. Enteritidis ATCC 13076). There was almost complete elimination of viable bacteria in milk after $24 \mathrm{~h}$ and $48 \mathrm{~h}$ at $4{ }^{\circ} \mathrm{C}$ with an MOI of 10,000 and 1000 (Figure 4C). Biocontrol by LPST94 resulted in decreasing viable Salmonella counts of at least $2.48 \log _{10} \mathrm{CFU} / \mathrm{mL}$ and $1.22 \log _{10} \mathrm{CFU} / \mathrm{mL}$ with an MOI of 10,000 and 1000 at $25^{\circ} \mathrm{C}$, respectively (Figure 4D).
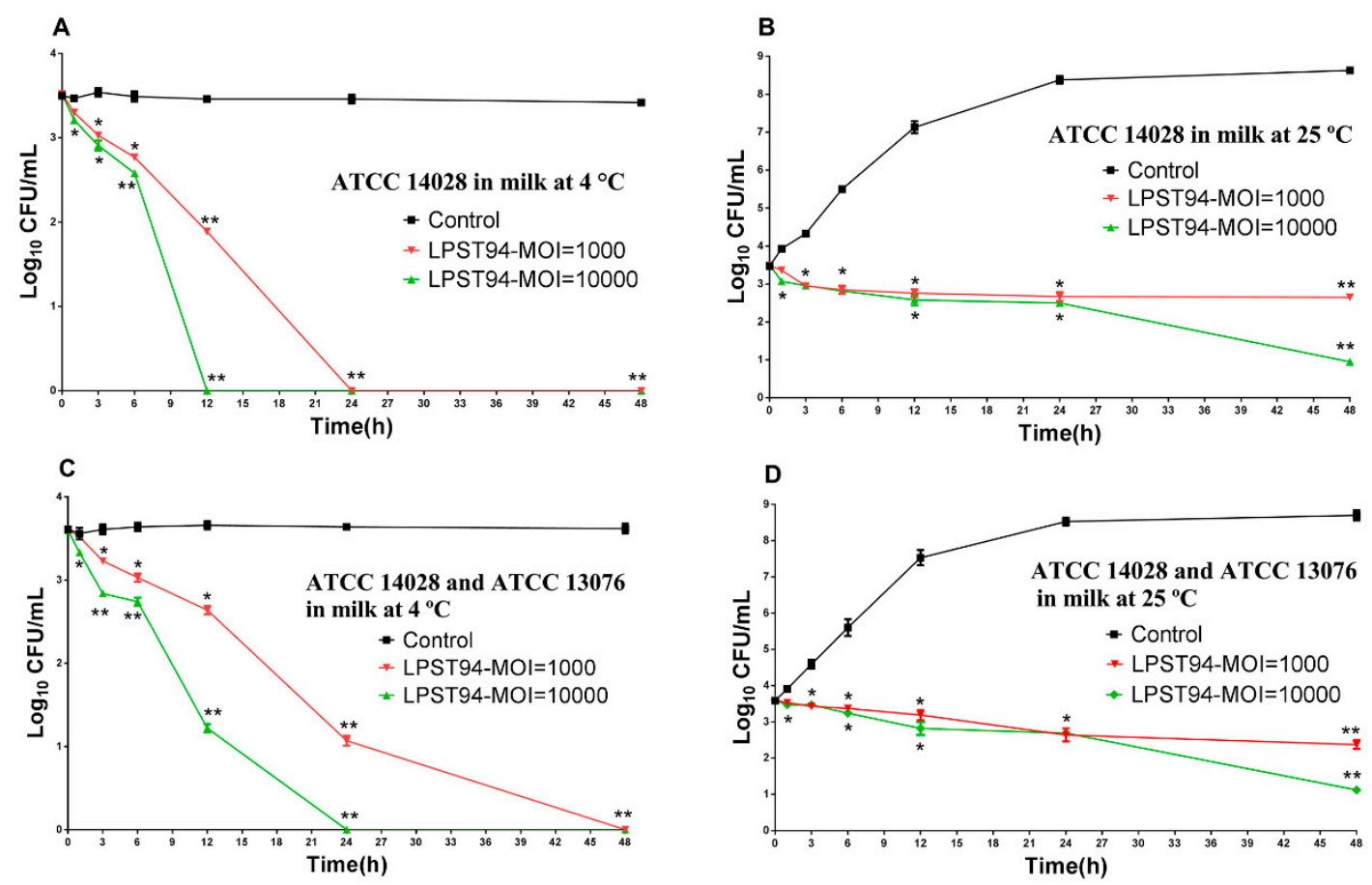

Figure 4. Effectiveness of phage LPST94 in reducing the S. Typhimurium ATCC 14028 and S. Enteritidis ATCC 13076 in milk. (A) Effect of phage LPST94 on growth of S. Typhimurium ATCC 14,028 in milk at $4{ }^{\circ} \mathrm{C}$, (B) Effect of phage LPST94 on growth of $S$. Typhimurium ATCC 14028 in milk at $25^{\circ} \mathrm{C},(\mathbf{C})$ Effect of phage LPST94 on growth of Salmonella mixture (S. Typhimurium ATCC 14028 and S. Enteritidis ATCC 13076) in milk at $4{ }^{\circ} \mathrm{C}$, and (D) Effect of phage LPST94 on growth of Salmonella mixture (S. Typhimurium ATCC 14028 and S. Enteritidis ATCC 13076) in milk at $25^{\circ} \mathrm{C}$. Values represent mean with standard deviation of three determinations. ${ }^{* *}$ Significance of $p<0.01$; ${ }^{*}$ Significance of $p<0.05$.

\subsubsection{Apple Juice}

Similar to the milk model, apple juice was artificially inoculated with $S$. Typhimurium (ATCC 14028) alone or as a mixture of Salmonella (S. Typhimurium ATCC 14028 and S. Enteritidis ATCC 13076) to $3 \log _{10} \mathrm{CFU} / \mathrm{mL}$. Relative to the non-treated controls, the viable Salmonella counts (S. Typhimurium) were reduced by using LPST94 at an MOI of 10,000 and 1000. When incubated at $4{ }^{\circ} \mathrm{C}$, the addition of LPST94 at an MOI of 10,000 and 1000, resulted in the Salmonella viable counts falling below the detection threshold after $12 \mathrm{~h}$ and $24 \mathrm{~h}$, respectively (Figure 5A). Similar results were also observed when samples were incubated at $25^{\circ} \mathrm{C}$, where the Salmonella counts were eliminated after $12 \mathrm{~h}$ and $24 \mathrm{~h}$ 
upon application of phage at an MOI of 10,000 and 1000, respectively (Figure 5B). Figure 5C shows that when phage LPST94 was applied at $4{ }^{\circ} \mathrm{C}$ against a mixture of $S$. Typhimurium ATCC14028 and ATCC13076 with an MOI of 10,000 and 1000, viable count of the bacteria was significantly reduced to undetectable levels after $12 \mathrm{~h}$ and $24 \mathrm{~h}$ respectively, which was consistent with the single Salmonella strain model. However, when LPST94 was applied to the Salmonella host mixture at $25^{\circ} \mathrm{C}$, the phage anti-bacterial efficiency was comparatively impaired, since the time to reach undectable levels were increased to $24 \mathrm{~h}$ and 48 husing the similar MOIs of 10,000 and 1000 (Figure 5D).
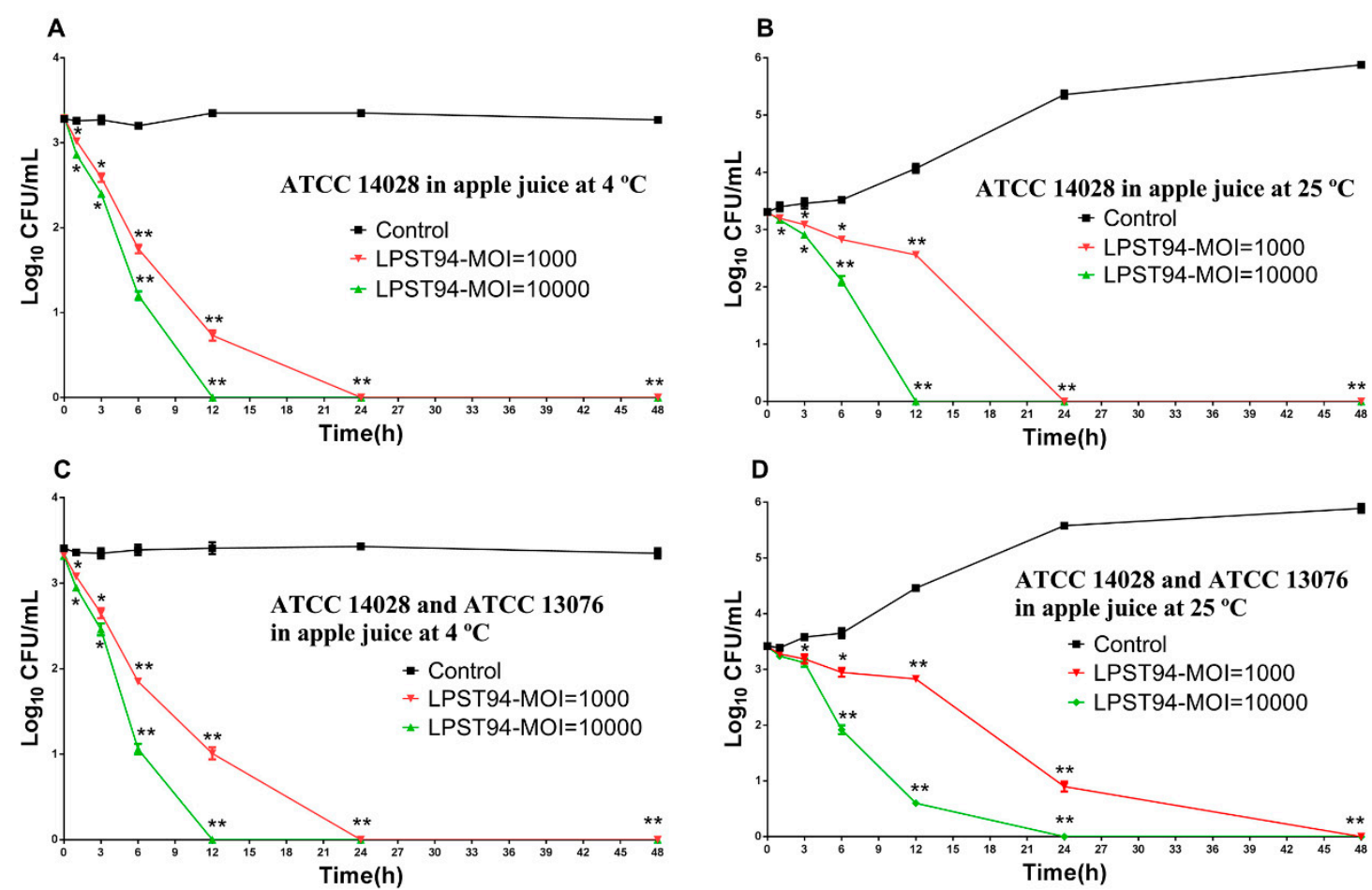

Figure 5. Effectiveness of phage LPST94 in reducing the S. Typhimurium ATCC 14028 and S. Enteritidis ATCC 13076 in apple juice. (A) Effect of phage LPST94 on growth of S. Typhimurium ATCC 14028 in apple juice at $4{ }^{\circ} \mathrm{C}$, (B) Effect of phage LPST94 on growth of $S$. Typhimurium ATCC 14028 in apple juice at $25^{\circ} \mathrm{C},(\mathrm{C})$ Effect of phage LPST94 on growth of Salmonella mixture (S. Typhimurium ATCC 14028 and S. Enteritidis ATCC 13076) in apple juice at $4{ }^{\circ} \mathrm{C}$, and (D) Effect of phage LPST94 on growth of Salmonella mixture (S. Typhimurium ATCC 14028 and S. Enteritidis ATCC 13076) in apple juice at $25^{\circ} \mathrm{C}$. Values represent mean with standard deviation of three determinations. ${ }^{* *}$ Significance of $p<0.01$; * Significance of $p<0.05$.

\subsubsection{Chicken Breast}

Phage LPST94 conferred an appreciable reduction of viable Salmonella counts on chicken breasts at both $4{ }^{\circ} \mathrm{C}$ and $25^{\circ} \mathrm{C}$ with MOIs of 10,000 and 1000 (Figure 6). When administered at an MOI of 10,000, phage LPST 94 reduced viable Salmonella below the level of detection at $4{ }^{\circ} \mathrm{C}$ after $6 \mathrm{~h}$ (Figure $6 \mathrm{~A}$ ) and at $25^{\circ} \mathrm{C}$ after $12 \mathrm{~h}$ of incubation (Figure 6B). In the case of an MOI of 1000 inoculation, LPST94 eliminated surviving Salmonella below detectable limits after $12 \mathrm{~h}$ of incubation at both at $4{ }^{\circ} \mathrm{C}$ (Figure $6 \mathrm{~A}$ ) and $25^{\circ} \mathrm{C}$ (Figure 6B). The mixture of Salmonella was also eliminated with MOIs of 10,000 and 1000 at both $4{ }^{\circ} \mathrm{C}$ (Figure $6 \mathrm{C}$ ) and $25^{\circ} \mathrm{C}$ (Figure 6D), although, the incubation period for this complete reduction was $12 \mathrm{~h}$ for each. 

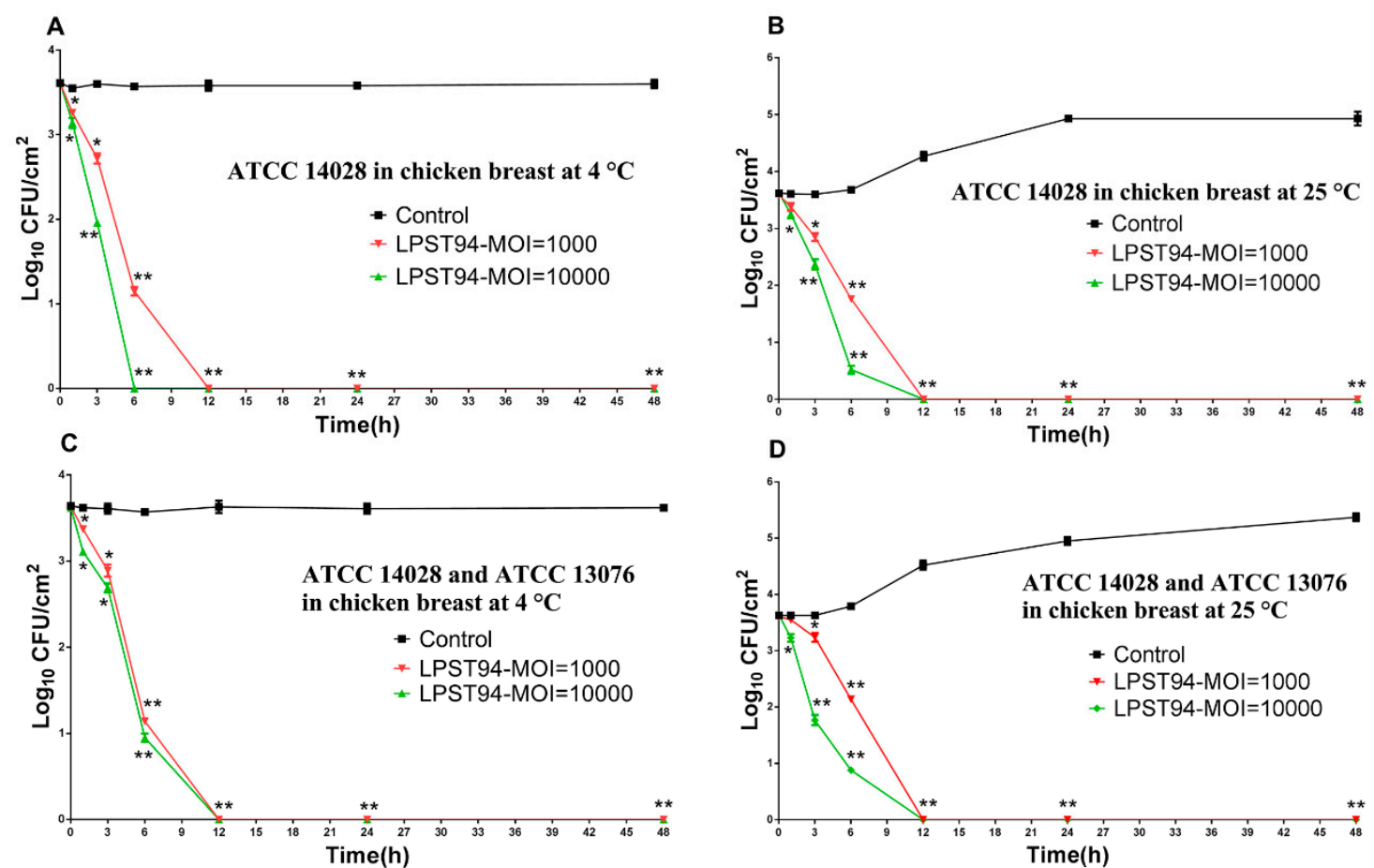

Figure 6. Effectiveness of phage LPST94 in reducing the S. Typhimurium ATCC 14028 and S. Enteritidis ATCC 13076 in chicken breast. (A) Effect of phage LPST94 on growth of S. Typhimurium ATCC 14028 on chicken breast at $4{ }^{\circ} \mathrm{C}$, (B) Effect of phage LPST94 on growth of $S$. Typhimurium ATCC 14028 on chicken breast at $25^{\circ} \mathrm{C},(\mathrm{C})$ Effect of phage LPST94 on growth of Salmonella mixture (S. Typhimurium ATCC 14028 and S. Enteritidis ATCC 13076) on chicken breast at $4{ }^{\circ} \mathrm{C}$, and (D) Effect of phage LPST94 on growth of Salmonella mixture (S. Typhimurium ATCC 14028 and S. Enteritidis ATCC 13076) on chicken breast at $25{ }^{\circ} \mathrm{C}$. Values represent mean with standard deviation of three determinations. ${ }^{* *}$ Significance of $p<0.01$; Significance of $p<0.05$.

\subsubsection{Lettuce}

The ability of the phage to reduce the artificial Salmonella contamination of lettuce was also demonstrated, with reductions below the level of detection for Salmonella at $4{ }^{\circ} \mathrm{C}$ and $25^{\circ} \mathrm{C}$ after $6 \mathrm{~h}$ using an MOI of 10,000 and 1000, respectively (Figure 7A,B). The effect of phage against a mixture of Salmonella on lettuce was comparable with no viable Salmonella observed at $4{ }^{\circ} \mathrm{C}$ after $6 \mathrm{~h}$ and $12 \mathrm{~h}$ using an MOI of 10,000 and 1000, respectively (Figure 7C). Likewise, there was a complete reduction of the mixture of Salmonella at $25^{\circ} \mathrm{C}$ after $12 \mathrm{~h}$ (Figure 7D). 

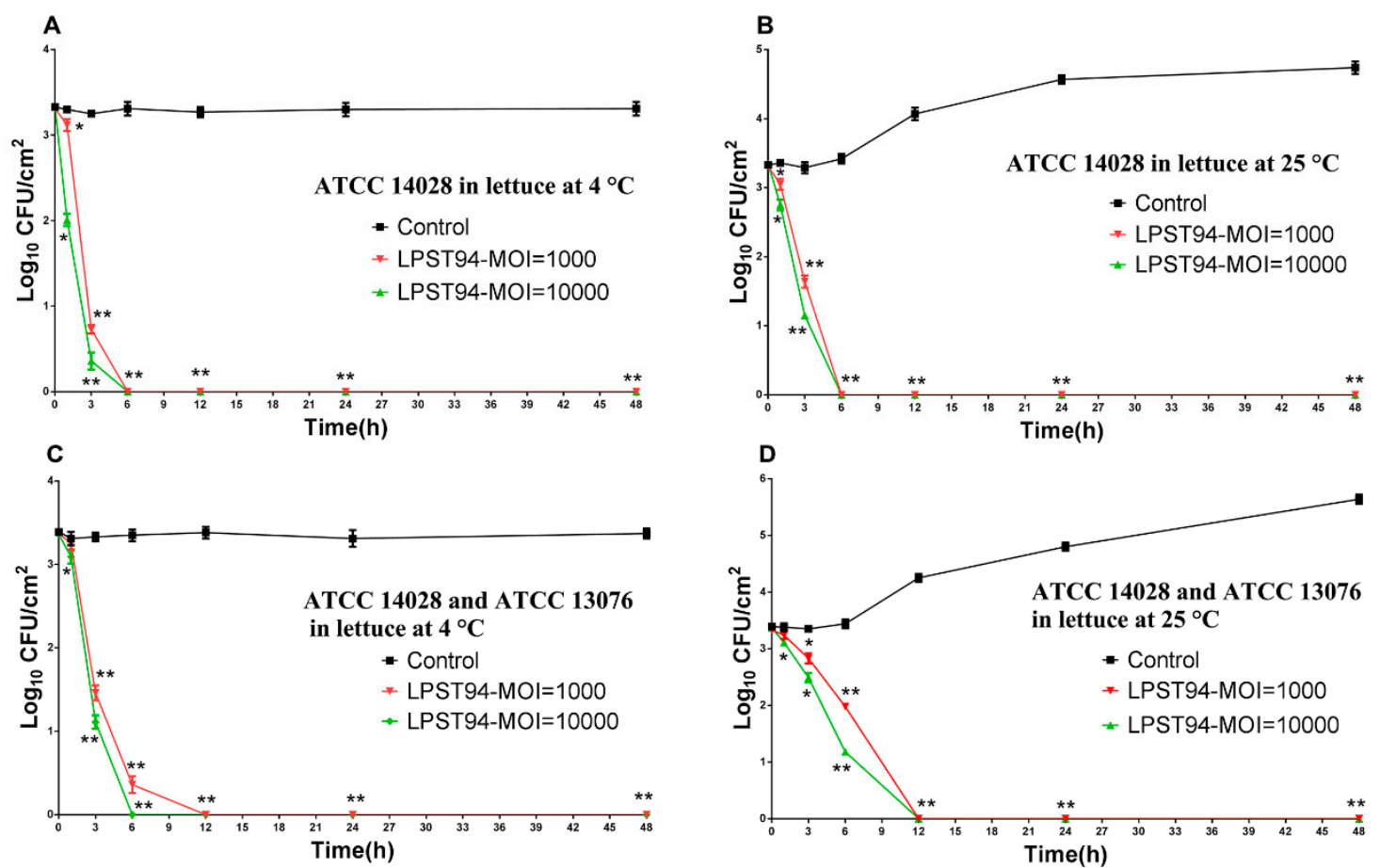

Figure 7. Effectiveness of phage LPST94 in reducing the $S$. Typhimurium ATCC 14028 and S. Enteritidis ATCC 13076 in lettuce. (A) Effect of phage LPST94 on growth of S. Typhimurium ATCC 14028 on lettuce at $4{ }^{\circ} \mathrm{C}$, (B) Effect of phage LPST94 on growth of $S$. Typhimurium ATCC 14028 on lettuce at $25^{\circ} \mathrm{C}$, (C) Effect of phage LPST94 on growth of Salmonella mixture (S. Typhimurium ATCC 14028 and S. Enteritidis ATCC 13076) on lettuce at $4{ }^{\circ} \mathrm{C}$, and (D) Effect of phage LPST94 on growth of Salmonella mixture (S. Typhimurium ATCC 14028 and S. Enteritidis ATCC 13076) on lettuce at $25^{\circ} \mathrm{C}$. Values represent mean with standard deviation of three determinations. ${ }^{* *}$ Significance of $p<0.01$; * Significance of $p<0.05$.

\section{Discussion}

In this study, 40 putative different phages were isolated from the environmentally sourced water samples and screened to identify a novel broadly acting phage against Salmonella species [52,53]. Based on lytic spectrum analysis, phage LPST94 showed a wide lytic range and related lytic activity against all 11 Salmonella serovars tested including S. Typhimurium, S. Enteritidis, S. Pullorum, S. Dublin, S. Anatum, S. Arizonae, S. Javiana, S. Kentucky, S. Newport, S. Paratyphi B, and S. Choleraesuls. Interestingly, phage LPST94 could also lyse multi-drug-resistant Salmonella. Clear plaques were observed for all 18 multi-drug-resistant Salmonella strains tested after phage LPST94 infection.

Phage LPST94 had high lytic activity against all the Salmonella in vitro and could inhibit the growth of 4 Salmonella (S. Typhimurium UK-1, S. Typhimurium ATCC 14028, S. Enteritidis ATCC 13076 and S. Enteritidis SGSC4901) for up to $11 \mathrm{~h}$ at MOIs of $0.1,1,10$, and 100. In comparison, the phage FGCSSa1 was reported to inhibit growth of their host (S. Typhimurium PT160) for up to $2 \mathrm{~h}$ at MOIs of 0.3 and 2.5 [52].

Transmission electron microscopy and genome analysis confirmed that phage LPST94 belonged to the Ackermannviridae family. Phage morphology with long tails were considered as professionally lytic phage types [54], which can be used in phage-based antibacterial strategies [55]. Phage LPST94 was robust, exhibiting stability over the $\mathrm{pH}$ range 4 to 12 and able to maintain lysis activity at $60^{\circ} \mathrm{C}$ for at least $60 \mathrm{~min}$. The $\mathrm{pH}$ and thermal stability of phage LPST94 indicate that it may be applied for biocontrol over a variety of conditions employed in food processing. This study showed that phage remained stable over $48 \mathrm{~h}$ in milk, chicken breast, and lettuce but $2.5 \log _{10} \mathrm{PFU} / \mathrm{mL}$ losses were observed in apple juice potentially due to presence of weak acid. However, small losses in phage titers 
in diverse food samples (Chinese cabbage, chicken breast, mixed seafood, and chocolate milk) have been observed by other researches [28,47]. These results suggest that phage LPST94 has clear potential to be applied on raw and processed food samples.

We further determined the efficiency of this phage to reduce the counts of Salmonella within foods. In experiments with milk, phage LPST94 reduced viable Salmonella counts $3 \log _{10}$ at $4{ }^{\circ} \mathrm{C}$ and $2.56 \log _{10}$ $\mathrm{CFU} / \mathrm{mL}$ at $25^{\circ} \mathrm{C}$ after $48 \mathrm{~h}$ incubation, which was of greater efficiency when compared with phage PA 13076 that was reported to reduce $S$. Enteritidis ATCC 13076 by $1 \log _{10} \mathrm{CFU} / \mathrm{mL}$ at $4{ }^{\circ} \mathrm{C}$ and $25^{\circ} \mathrm{C}$ after $5 \mathrm{~h}$ incubation in milk [28]. Within apple juice, phage LPST94 reduced Salmonella by $3 \log _{10}$ at $4{ }^{\circ} \mathrm{C}$ after $12 \mathrm{~h}$ incubation using an MOI of 10,000, similar to that reported for phage P22 [56]. In chicken breast and lettuce, Salmonella counts dropped below detectable levels $(<1 \mathrm{CFU} / 100 \mu \mathrm{L})$ at $4{ }^{\circ} \mathrm{C}$ and $25^{\circ} \mathrm{C}$ from $6 \mathrm{~h}$ to $12 \mathrm{~h}$ of incubation. This may be compared with a $3 \log _{10}$ reduction in the Salmonella viable count reported after phage treatment for Chinese cabbage [28], $1.7 \log _{10}$ reduction for lettuce [26], $1.37 \log _{10}$ for mustard and $0.55 \log _{10}$ reduction for broccoli [57].

Genomic sequence analysis of phage LPST94 revealed similarity to phage PhiSH19 but with novel features that confer prospective functions for infection and proliferation. Phage LPST94 genome contained genes for structure and replication/recombination/repair, nucleotide metabolism, transcription, translation and additional functions for phage. These results indicated that this phage could replicate efficiently but was unable to form a lysogen in Salmonella [58-60]. In addition, a feature of phage LPST94 was that it encoded several different tail spike proteins which are hypothesized as an indicator of a broad lytic range [61]. The tail spikes primary recognize, attach, and cleave the LPS O-antigen of S. Typhimurium [62]. Moreover, the phage genome did not encode any virulence genes, toxins, drug-resistant markers or integration genes, indicating that this phage has the potential for being developed as an alternative antimicrobial agent without any harmful effects on humans and animals.

\section{Conclusions}

We have isolated a novel broad host lytic phage LPST94 against diverse Salmonella serovars. Phage LPST94 exhibited tolerance against a range $\mathrm{pH}$, thermal conditions, and stability for $48 \mathrm{~h}$ upon incubation with different food samples, properties that are a prerequisite for a biocontrol agent that can be directly applied in food samples. Further study showed this phage can effectively control Salmonella strains in a variety of food samples (milk, apple juice, chicken breast, and lettuce), suggesting phage LPST94 is a prime candidate for the biological control of Salmonella.

Supplementary Materials: The following are available online at http://www.mdpi.com/2076-2607/8/2/247/s1. Figure S1. Confirmation of LPST94 was unable to form lysogen. Induced by mitomycin C, found to contain lysogenic phage. Table S1. List of bacterial strains used in this study. Table S2. Functional annotation of LPST94 CDSs using BLASTP and conserved domains. Table S3. Comparison of phages against the LPST94 genome. Table S4. Antibiotics resistance profiles of the clinical isolates of Salmonella.

Author Contributions: This work was carried out in collaboration with all authors. Conceptualization, M.S.I., Y.Z., and J.L.; Data curation, M.S.I., I.N., Y.Z., and T.Y.; Formal analysis, M.S.I., and J.L.; Funding acquisition, J.L.; Investigation, M.S.I., Y.Z., and J.L.; Methodology, M.S.I., Y.Z. and I.N.; Project administration, M.S.I. and J.L.; Resources, M.S.I., J.L.; Software, M.S.I. and J.L.; Supervision, J.L.; Validation, M.S.I. and J.L.; Visualization, M.S.I., Y.Z. and J.L.; Writing—original draft, M.S.I.; Writing—review \& editing, J.L., M.S.I., L.L., S.P.W., M.Z.M., W.B., I.F.C., V.A.F. and Y.Z. All authors have read and agreed to the published version of the manuscript.

Funding: This research was supported by the National Natural Science Foundation of China (31772083), Special fund for Technology Innovation of Hubei Province (2019AHB07), the National Key Research and Development Program of China (2017YFC1600100), the Fundamental Research Funds for the Central Universities (2662017JC040, 2662016QD010), China Scholarship Council (201806765004) and the National Innovation and Entrepreneurship Training Program for Undergraduates (S201910504071, 201810504087).

Conflicts of Interest: All authors have no conflicts of interest to declare. 


\section{References}

1. Balasubramanian, R.; Im, J.; Lee, J.-S.; Jeon, H.J.; Mogeni, O.D.; Kim, J.H.; Rakotozandrindrainy, R.; Baker, S.; Marks, F. The global burden and epidemiology of invasive non-typhoidal Salmonella infections. Hum. Vaccines Immunother. 2019, 15, 1421-1426. [CrossRef]

2. Haraga, A.; Ohlson, M.B.; Miller, S.I. Salmonellae interplay with host cells. Nat. Rev. Microbiol. 2008, 6, 53-66. [CrossRef] [PubMed]

3. Pui, C.F.; Wong, W.C.; Chai, L.C.; Tunung, R.; Jeyaletchumi, P.; Hidayah, M.S.N.; Ubong, A.; Farinazleen, M.G.; Cheah, Y.K. Salmonella: A foodborne pathogen. Int. Food Res. J. 2011, 18, 465-473.

4. Scallan, E.; Hoekstra, R.M.; Angulo, F.J.; Tauxe, R.V.; Widdowson, M.A.; Roy, S.L.; Jones, J.L.; Griffin, P.M. Foodborne illness acquired in the United States-major pathogens. Emerg. Infect. Dis. 2011, 17, 16-22. [CrossRef] [PubMed]

5. Multistate Outbreak of Salmonella Typhimurium Linked to Chicken Salad. Centers for Disease Control and Prevention. 2018. Available online: https://www.cdc.gov/salmonella/typhimurium-02-8/index.html (accessed on 11 October 2018).

6. Huang, X.; Huang, Q.; Dun, Z.; Huang, W.; Wu, S.; Liang, J.; Deng, X.; Zhang, Y. Nontyphoidal Salmonella Infection, Guangdong Province, China, 2012. Emerg. Infect. Dis. 2016, 22, 726-729. [CrossRef]

7. Miao, E.A.; Miller, S.I. Bacteriophages in the evolution of pathogen-host interactions. Proc. Natl. Acad. Sci. USA 1999, 96, 9452. [CrossRef]

8. Tauxe, R.V.; Doyle, M.P.; Kuchenmã $\frac{1}{4}$ Ller, T.; Schlundt, J.; Stein, C.E. Evolving public health approaches to the global challenge of foodborne infections. Int. J. Food Microbiol. 2010, 139, S16-S28. [CrossRef]

9. Juneja, V.K.; Dwivedi, H.P.; Yan, X. Novel natural food antimicrobials. Annu. Rev. Food Sci. Technol. 2012, 3, 381-403. [CrossRef]

10. Neetoo, H.; Mahomoodally, F. Use of Antimicrobial Films and Edible Coatings Incorporating Chemical and Biological Preservatives to Control Growth of Listeria monocytogenes on Cold Smoked Salmon. BioMed Res. Int. 2014, 534915, 10.

11. Musyoka, J.N.; Abong, G.O.; Mbogo, D.M.; Fuchs, R.; Low, J.; Heck, S.; Muzhingi, T. Effects of Acidification and Preservatives on Microbial Growth during Storage of Orange Fleshed Sweet Potato Puree. Int. J. Food Sci. 2018, 2018, 7435-7443. [CrossRef]

12. Omer Mukhtar, T.; Syed Abdul, A.; Khalid, J.; Askari, B. Study to evaluate the impact of heat treatment on water soluble vitamins in milk. JPMA J. Pak. Med. Assoc. 2010, 60, 909.

13. Leskova, E.; Kubíková, J.; Kováčiková, E.; Košická, M.; Porubská, J.; Holčíková, K. Vitamin losses: Retention during heat treatment and continual changes expressed by mathematical models. J. Food Compos. Anal. 2006, 19, 252-276. [CrossRef]

14. Pawlowska, A.M.; Zannini, E.; Coffey, A.; Arendt, E.K. “Green preservatives”: Combating fungi in the food and feed industry by applying antifungal lactic acid bacteria. Adv. Food Nutr. Res. 2012, 66, 217. [PubMed]

15. Khoshnoud, M.J.; Siavashpour, A.; Bakhshizadeh, M.; Rashedinia, M. Effects of sodium benzoate, a commonly used food preservative, on learning, memory, and oxidative stress in brain of mice. J. Biochem. Mol. Toxicol. 2017, 32, 2. [CrossRef]

16. Uribarri, J.; Woodruff, S.; Goodman, S.; Cai, W.; Chen, X.; Pyzik, R.; Yong, A.; Striker, G.E.; Vlassara, H. Advanced glycation end products in foods and a practical guide to their reduction in the diet. J. Am. Diet. Assoc. 2010, 110, 911-916. [CrossRef]

17. Wei, S.; Chelliah, R.; Rubab, M.; Oh, D.-H.; Uddin, M.J.; Ahn, J. Bacteriophages as Potential Tools for Detection and Control of Salmonella spp. in Food Systems. Microorganisms 2019, 7, 570. [CrossRef]

18. Svircev, A.; Roach, D.; Castle, A. Framing the Future with Bacteriophages in Agriculture. Viruses 2018, 10, 218. [CrossRef]

19. Furfaro, L.L.; Payne, M.S.; Chang, B.J. Bacteriophage Therapy: Clinical Trials and Regulatory Hurdles. Front. Cell. Infect. Microbiol. 2018, 8, 376. [CrossRef]

20. Bumunang, E.W.; McAllister, T.A.; Stanford, K.; Anany, H.; Niu, Y.D.; Ateba, C.N. Characterization of Non-O157 STEC Infecting Bacteriophages Isolated from Cattle Faeces in North-West South Africa. Microorganisms 2019, 7, 615. [CrossRef]

21. Sillankorva, S.M. Bacteriophages and Their Role in Food Safety. Int. J. Microbiol. 2012, 1, 13. [CrossRef] 
22. Blasco, L.; Ambroa, A.; Lopez, M.; Fernandez-Garcia, L. Combined Use of the Ab105-2phiDeltaCI Lytic Mutant Phage and Different Antibiotics in Clinical Isolates of Multi-Resistant Acinetobacter baumannii. Microorg. 2019, 7, 556. [CrossRef] [PubMed]

23. Mccallin, S.; Alam, S.S.; Barretto, C.; Sultana, S.; Berger, B.; Huq, S.; Krause, L.; Bibiloni, R.; Schmitt, B.; Reuteler, G. Safety analysis of a Russian phage cocktail: From metagenomic analysis to oral application in healthy human subjects. Virology 2013, 443, 187-196. [CrossRef] [PubMed]

24. Shafiqul Alam, S.; Shawna, M.C.; Caroline, B.; Bernard, B.; Anne-Cécile, P.; Shamima, S.; Lutz, K.; Sayeda, H.; Rodrigo, B.; Anne, B. Oral T4-like phage cocktail application to healthy adult volunteers from Bangladesh. Virology 2012, 434, 222-232.

25. O'Flynn, G.; Coffey, A.; Fitzgerald, G.F.; Ross, R.P. The newly isolated lytic bacteriophages st104a and st104b are highly virulent against Salmonella enterica. J. Appl. Microbiol. 2006, 101, 251-259. [CrossRef]

26. Spricigo, D.A.; Bardina, C.; Cortés, P.; Llagostera, M. Use of a bacteriophage cocktail to control Salmonella in food and the food industry. Int. J. Food Microbiol. 2013, 165, 169-174. [CrossRef]

27. Albino, L.A.; Rostagno, M.H.; Húngaro, H.M.; Mendonça, R.C. Isolation, characterization, and application of bacteriophages for Salmonella spp. biocontrol in pigs. Foodborne Pathog. Dis. 2014, 11, 602-609. [CrossRef]

28. Bao, H.; Zhang, P.; Zhang, H.; Zhou, Y.; Zhang, L.; Wang, R. Bio-Control of Salmonella Enteritidis in Foods Using Bacteriophages. Viruses 2015, 7, 4836-4853. [CrossRef]

29. Galarce, N.; Escobar, B.; Rojas, V.; Navarro, C.; Turra, G.; Robeson, J.; Borie, C. Application of a virulent bacteriophage cocktail leads to reduction of serovar Enteritidis counts in processed meat products. Biocontrol Sci. Technol. 2016, 26, 1-26. [CrossRef]

30. Sukumaran, A.T.; Nannapaneni, R.; Kiess, A.; Sharma, C.S. Reduction of Salmonella on chicken meat and chicken skin by combined or sequential application of lytic bacteriophage with chemical antimicrobials. Int. J. Food Microbiol. 2015, 207, 8-15. [CrossRef]

31. Goodridge, L.D.; Bisha, B. Phage-based biocontrol strategies to reduce foodborne pathogens in foods. Bacteriophage 2011, 1, 130-137. [CrossRef]

32. Samson, J.E.; Magadán, A.H.; Sabri, M.; Moineau, S. Revenge of the phages: Defeating bacterial defences. Nat. Rev. Microbiol. 2013, 11, 675-687. [CrossRef]

33. Doron, S.; Melamed, S.; Ofir, G.; Leavitt, A.; Lopatina, A.; Keren, M.; Amitai, G.; Sorek, R. Systematic discovery of antiphage defense systems in the microbial pangenome. Science 2018, 359, eaar4120. [CrossRef]

34. Akhtar, M.; Viazis, S.; Diez-Gonzalez, F. Isolation, identification and characterization of lytic, wide host range bacteriophages from waste effluents against Salmonella enterica serovars. Food Control 2014, 38, 67-74. [CrossRef]

35. Islam, M.S.; Zhou, Y.; Liang, L.; Nime, I.; Liu, K.; Yan, T.; Wang, X.; Li, J. Application of a Phage Cocktail for Control of Salmonella in Foods and Reducing Biofilms. Viruses 2019, 11, 841. [CrossRef]

36. Van, T.R.; Kropinski, A.M. Bacteriophage enrichment from water and soil. Methods Mol. Biol. 2009, 501, 15-21.

37. Jin, W.J.; Park, S.C.; Wicklund, A.; Skurnik, M. Bacteriophages reduce Yersinia enterocolitica contamination of food and kitchenware. Int. J. Food Microbiol. 2018, 271, 33-47. [CrossRef]

38. Costa, P.; Pereira, C.; Gomes, A.T.P.C.; Almeida, A. Efficiency of Single Phage Suspensions and Phage Cocktail in the Inactivation of Escherichia coli and Salmonella Typhimurium: An In Vitro Preliminary Study. Microorganisms 2019, 7, 94. [CrossRef]

39. Ackermann, H.W. Phage classification and characterization. Methods Mol. Biol. 2009, 501, 127.

40. Islam, M.S.; Raz, A.; Liu, Y.; Elbassiony, K.R.A.; Dong, X.; Zhou, P.; Zhou, Y.; Li, J. Complete Genome Sequence of Aeromonas Phage ZPAH7 with Halo Zones, Isolated in China. Microbiol. Resour. Announc. 2019, 8, e01678-18. [CrossRef]

41. Delcher, A.L.; Bratke, K.A.; Powers, E.C.; Salzberg, S.L. Identifying bacterial genes and endosymbiont DNA with Glimmer. Bioinformatics 2007, 23, 673-679. [CrossRef]

42. Mount, D.W. Using the basic local alignment search tool (BLAST). C.S.H. Protoc. 2007, 7, pdb-top17. [CrossRef]

43. Son, H.M.; Duc, H.M.; Masuda, Y.; Honjoh, K.I.; Miyamoto, T. Application of bacteriophages in simultaneously controlling Escherichia coli O157:H7 and extended-spectrum beta-lactamase producing Escherichia coli. Appl. Microbiol. Biotechnol. 2018, 102, 10259-10271. [CrossRef] 
44. Pinheiro, L.A.M.; Pereira, C.; Frazão, C.; Balcão, V.M.; Almeida, A. Efficiency of Phage $\varphi 6$ for Biocontrol of Pseudomonas syringae pv. syringae: An in Vitro Preliminary Study. Microorganisms 2019, 7, 286. [CrossRef]

45. Tseng, C.-C.; Chang, D.C.; Chang, K.-C. Development of a Biocontrol Method Applying BacteriophageContaining Aerosol against Mycobacterium tuberculosis Using the Bacteriophage BTCU-1 and M. smegmatis as Models. Microorganisms 2019, 7, 237. [CrossRef]

46. Lópezcuevas, O.; Castrodel, C.N.; Leónfélix, J.; Gonzálezrobles, A.; Chaidez, C. Characterization of bacteriophages with a lytic effect on various Salmonella serotypes and Escherichia coli O157:H7. Can. J. Microbiol. 2011, 57, 1042. [CrossRef]

47. Guenther, S.; Herzig, O.; Fieseler, L.; Klumpp, J.; Loessner, M.J. Biocontrol of Salmonella Typhimurium in RTE foods with the virulent bacteriophage FO1-E2. Int. J. Food Microbiol. 2012, 154, 66-72. [CrossRef]

48. Pereira, C.; Moreirinha, C.; Lewicka, M.; Almeida, P.; Clemente, C.; Cunha, Â.; Delgadillo, I.; Romalde, J.L.; Nunes, M.L.; Almeida, A. Bacteriophages with potential to inactivate Salmonella Typhimurium: Use of single phage suspensions and phage cocktails. Virus Res. 2016, 220, 179-192. [CrossRef]

49. Laguerre, O.; Derens, E.; Palagos, B. Study of domestic refrigerator temperature and analysis of factors affecting temperature: A French survey. Int. J. Refrig. 2002, 25, 653-659. [CrossRef]

50. Mirzaei, M.K.; Nilsson, A.S. Isolation of Phages for Phage Therapy: A Comparison of Spot Tests and Efficiency of Plating Analyses for Determination of Host Range and Efficacy. PLoS ONE 2015, 10, e0118557. [CrossRef]

51. Mouttotou, N.; Ahmad, S.; Kamran, Z.; Koutoulis, K.C. Prevalence, Risks and Antibiotic Resistance of Salmonella in Poultry Production Chain. Curr. Top. Salmonella Salmonellosis 2017. [CrossRef]

52. Careysmith, G.V.; Billington, C.; Cornelius, A.J.; Hudson, J.A.; Heinemann, J.A. Isolation and characterization of bacteriophages infecting Salmonella spp. FEMS Microbiol. Lett. 2006, 258, 182-186. [CrossRef]

53. Bielke, L.; Higgins, S.; Donoghue, A.; Donoghue, D.; Hargis, B.M. Salmonella Host Range of Bacteriophages That Infect Multiple Genera. Poult. Sci. 2007, 86, 2536-2540. [CrossRef]

54. Hobbs, Z.; Abedon, S.T. Diversity of phage infection types and associated terminology: The problem with "Lytic or Lysogenic". FEMS Microbiol. Lett. 2016, 363, fnw047. [CrossRef]

55. Sunderland, K.; Yang, M.; Mao, C. Phage-Enabled Nanomedicine: From Probes to Therapeutics in Precision Medicine. Angew. Chem. 2016, 56, 1964. [CrossRef]

56. Zinno, P.; Devirgiliis, C.; Ercolini, D.; Ongeng, D.; Mauriello, G. Bacteriophage P22 to challenge Salmonella in foods. Int. J. Food Microbiol. 2014, 191, 69-74. [CrossRef]

57. Pao, S.; Rolph, S.P.; Westbrook, E.W.; Shen, H. Use of Bacteriophages to Control Salmonella in Experimentally Contaminated Sprout Seeds. J. Food Sci. 2004, 69, M127-M130. [CrossRef]

58. Seal, B.S.; Fouts, D.E.; Simmons, M.; Garrish, J.K.; Kuntz, R.L.; Woolsey, R.; Schegg, K.M.; Kropinski, A.M.; Ackermann, H.; Siragusa, G.R. Clostridium perfringens bacteriophages ФСР39O and ФСР26F: Genomic organization and proteomic analysis of the virions. Arch. Virol. 2011, 156, 25-35. [CrossRef]

59. Li, X.; Heyer, W.D. Homologous recombination in DNA repair and DNA damage tolerance. Cell Res. 2008, 18, 99-113. [CrossRef]

60. Liu, Y.; Mi, L.; Mi, Z.; Huang, Y.; Li, P.; Zhang, X.; Tong, Y.; Bai, C. Complete Genome Sequence of IME207, a Novel Bacteriophage Which Can Lyse Multidrug-Resistant Klebsiella pneumoniae and Salmonella. Genome Announc. 2016, 4, e01015-e01016. [CrossRef]

61. Hooton, S.P.; Timms, A.R.; Rowsell, J.; Wilson, R.; Connerton, I.F. Salmonella Typhimurium-specific bacteriophage $\Phi S H 19$ and the origins of species specificity in the Vi01-like phage family. Virol. J. 2011, 8, 1-14. [CrossRef]

62. Steinbacher, S.; Baxa, U.; Miller, S.; Weintraub, A.; Seckler, R.; Huber, R. Crystal structure of phage P22 tailspike protein complexed with Salmonella sp. O-antigen receptors. Proc. Natl. Acad. Sci. USA 1996, 93, 10584-10588. [CrossRef]

(C) 2020 by the authors. Licensee MDPI, Basel, Switzerland. This article is an open access article distributed under the terms and conditions of the Creative Commons Attribution (CC BY) license (http://creativecommons.org/licenses/by/4.0/). 